\title{
Hawking's fact and fiction
}

George F. R. Ellis, with help from Ruby (10) Stephen Hawking's book A Brief History of Time was a huge commercial success. Its achievements in bringing difficult scientific ideas to a wide audience are not so clear. Now the distinguished physicist has teamed up with his daughter Lucy to produce a children's book designed to communicate contemporary physics. Will it capture the attention of young minds and teach them some real science? Or will it be boring and over the heads of the prospective readers?

George's Secret Key to the Universe is an adventure story complete with villains and hero and is illustrated with enjoyable line-drawings. It involves a lost pig, a humorously portrayed intelligent computer, school bullies and a trip through the Solar System. Didactic discussions on aspects of modern physics, such as supernova explosions and black-hole physics are hung on this set-up. There are also fact boxes on physics and astronomy, and some photographs of astronomical phenomena: planets, comets, galaxies and so on. Overall, the book is a serious effort to convey facts and ideas in present day astronomy and astrophysics, within a science-fiction adventure story.
The mixture is great. Children love facts and adventure stories. The combination will catch their interest and keep them occupied for hours. After ten minutes of leafing through the book, my granddaughter Ruby was deeply absorbed and I had to promise to bring it back for her to read after I had completed my review. Like any educational tool, it will succeed for some and not for others. I reckon there should be more of the former.

I have two small quibbles. First, there is a bit of a disjunction between the science and the science-fiction parts that could confuse: is the kind of space travel envisaged in the narrative compatible with the hard science in the science sections? I suspect not. Second, I find the cover garish. But my youthful consultant loved it; so who am I to query the taste of youth? George F. R. Ellis is professor of Mathematics at University of Cape Town, Rondebosch 7701, Cape Town, South Africa.
George's Secret Key to the Universe

By Lucy and Stephen Hawking

Doubleday: $€ 12.99$

Simon \& Schuster: $\$ 17.99$

\section{Stones, bones and stories}

\section{Henry Gee, with help from Phoebe (9) and Rachel (7)}

The 'life-as-grand-narrative' school of children's books, such as Spinar and Burian's spectacular Life Before Man, first published in 1972, tell the history of life as 'Manifest Destiny', in which isolated fossil remains are seen as parts of a preordained jigsaw.

Books like that have an undeniable appeal I loved them as a child. The determinedly oldfashioned Life Story, published in the late 1980s, is very much part of that tradition. "This book is captivating," says Phoebe, aged nine, "with its beautiful illustrations and words. I loved it!"

Phoebe is a chip off the old block, to whom the grand-narrative theme is an easy sell. The knack is to entice into the contemplation of life's splendid drama those children who might otherwise not have considered it - and, hopefully, to keep them there, enthralling them sufficiently that they spurn opportunities later on to become more interested in cell signalling or real estate.

How can this be done? Rachel is far less interested in the idea of dinosaurs as living animals than is her sister, but has a fine eye for a fossil in the field. For her, shapes and colours are as important as concept, and she enjoyed Neal Layton's calculatedly anarchic The Story of Everything, an elaborate pop-up book that looks like how Life Story would have turned out, had it been written by a mildly scatological graffiti artist.

In other words, what you need is a gimmick. The Pebble In My Pocket tries this through the valid, somewhat earnest mechanism of following the career of a pebble from its origins as volcanic lava until it ends up being picked up by a little girl 480 million years later: the history of life being told from the point of view of a pebble. The problem is that pebbles make unsympathetic narrators.

Ask Dr K Fisher About Dinosaurs is the other extreme - a scrapbook-like presentation of a collection of dinosaur problems solved by a prehistoric agony aunt. A juvenile T. rex, worried that his teeth are falling out, is consoled to learn that this is normal, and his teeth will be replaced. The children enjoyed the presentation, but it hardly lingered in the mind.

Fractionally more successful was Prehistoric Actual Size, in which parts of prehistoric animals - a tooth or a claw - are represented at their actual size. This is a clever idea, one of the thrills I get when seeing a museum specimen for the first time is realizing that the real thing is so much smaller (or larger) than I had imagined. But like many gimmicks, it's a onetrick pony.

The gimmick that works for everyone is to tell the history of life as a human story, in which real people are measured up against geological

\author{
Life Story \\ Eric Maddern \& Leo Duff (illus.) \\ Frances Lincoln: $€ 5.99$ \\ The Story of Everything \\ by Neal Layton \\ Hodder: $£ 12.99$ \\ The Pebble In My Pocket \\ by Meredith Hooper \& Chris Coady (illus.) \\ Frances Lincoln: $£ 5.99$ \\ Ask Dr K Fisher about Dinosaurs \\ by Claire Llewellyn \& Kate Sheppard (illus.) \\ Kingfisher: $€ 7.99$ \\ Prehistoric Actual Size \\ by Steve Jenkins \\ Frances Lincoln: $€ 11.99$ \\ The Fossil Girl \\ by Catherine Brighton \\ Frances Lincoln: $€ 5.99 / \$ 7.95$ \\ Stone Girl Bone Girl \\ by Laurence Anholt \& Sheila Moxley (illus.) \\ Frances Lincoln: $€ 5.99 / \$ 7.95$ \\ The Human Story \\ by Charles Lockwood \\ Natural History Museum: $£ 9.99$
}

time, to give it scale. So the big hits chez Gee were The Fossil Girl and Stone Girl Bone Girl, two books about Mary Anning (1799-1847), the young woman who excavated many important specimens of early Jurassic marine life from the cliffs at Lyme Regis on the south coast of 